\title{
EVALUATION OF THE HAEMOSTATIC POTENTIALS OF CRUDE METHANOLIC LEAF EXTRACT OF PERSEA AMERICANA IN WISTAR RATS
}

George C. Anigbo ${ }^{a}$, Onyekachi A. Onyekwere ${ }^{b *}$, Peter I. Akwukwaegbu $^{\mathrm{c}}$, Albert Lackson ${ }^{\mathrm{b}}$, Christopher D. Bando ${ }^{\mathrm{b}}$, Obinna M. Okoye ${ }^{\mathrm{c}}$, Azubuike B. Okoroafor ${ }^{\mathrm{d}}$, Patrick Esemaya ${ }^{\mathrm{b}}$, Patrick C. Okolo-Gift ${ }^{\mathrm{b}}$

${ }^{a}$ Department of Medical Laboratory Science, University of Nigeria, Nsukka, Enugu, Nigeria

${ }^{b}$ National Biotechnology Development Agency, Abuja, Nigeria ${ }^{c}$ Department of Biochemistry, University of Port Harcourt, Choba, Rivers, Nigeria

${ }^{d}$ Department of Pure \& Industrial Chemistry, University of Port Harcourt, Choba, Rivers, Nigeria

\begin{abstract}
To date, there is limited information on the coagulative and possible haemostatic potentials of Persea americana extract. In light of this, the study was aimed to investigate the haemostatic potentials of crude methanolic leaf extract of Persea americana in Wistar rats using standard analytical methods. A total of twenty-five adult male Wistar rats were arbitrarily distributed into five groups of five rats each and kept under suitable conditions for acclimatization and feeding. Group A was used as control and received feed and water only while various plant extracts (with concentrations 200, 400, 600 and $800 \mathrm{mg} / \mathrm{kg}$ ) were orally administered on daily basis per body weight of animal in addition to normal feed and water for thirty days to the test groups B-E. After 4 weeks, the animals were sacrificed painlessly and blood samples were collected by retro-orbital plexus of
\end{abstract}

*Onyekachi A. Onyekwere, e-mail: onyekachi.onyekwere.au@gmail.com 
the median canthus of the eyes. The prothrombin and activated partial thromboplastin times (PT and APTT), clotting and bleeding times (CT and BT) and plasma fibrinogen concentration were determined. Phytochemical screening of the leaf extract revealed substantial percentage of alkaloids, saponins, tannins, flavonoids, steroids and phenols. Results of the haemostatic potential showed a dose-dependent significant decrease $(\mathrm{P}<0.05)$ in the PT, APTT, CT, and BT and a slightly increase $(\mathrm{P}<0.05)$ in the plasma fibrinogen concentration when compared with the control. This study suggested that the leaf extract of Persea Americana had a stimulatory effect on intrinsic and extrinsic properties of the coagulation cascade.

Keywords: Persea americana, phytochemicals, coagulation, haemostatic potentials.

\section{Introduction}

Blood coagulation is a well-studied process involving clot formation at an injured blood vessel wall site. ${ }^{1}$ The coagulation cascade is a multi-step process which functions in a well-coordinated manner to hold blood firmly at an injury site and eventually stop bleeding. The cascade makes use of over ten different proteins coagulation factors which are found in the blood plasma. Usually, when there is a cut on the blood vessel either on the skin or other internal injuries, the blood vessel constricts thereby limiting the amount of blood flow through the vessel. Platelets are immediately activated as typical response to these injuries. The platelets stick together and to the wound site forming a plug with the help of a protein known as von Willebrand factor (VWF). ${ }^{2}$ Furthermore, the protein clotting factors will trigger the production of fibrin which is responsible for the formation of a fibrin clot that confers an increased stability. After a while (days to weeks), the clot is strengthened and further dissolved as the wounded blood vessel heals. An abnormality in blood coagulation leads to prolonged clotting time. Hence at trivial wounds, there would be excessive loss of blood. 
Plants as ingredients of traditional medicine proved to be a valuable source for various pharmaceutical drugs. More than $80 \%$ of the world's rural settlers use traditional medicine in their primary healthcare needs, most of which are plants sources. ${ }^{3}$ Persea americana is a tree plant usually called avocado or alligator pear. It is a large, spreading, evergreen tree with an irregular dense crown that can vary widely in height according to variety. It is a medium sized tree ranging from $15-20 \mathrm{~m}$ in height, ${ }^{4}$ belonging to the family of lauraceae. The plant is native to Mexico but is also found in many tropical countries including Nigeria. Persea americana is widely used in medicine in order to alleviate some medical conditions such as hypertension, diabetes, inflammation, etc. ${ }^{5,6,7}$ The leaves were used successfully in the treatment of hypertension, ${ }^{8,6}$ sore throat, hemorrhages and inflammatory conditions. Various activities of leaves components were reported so far. Antihypertensive activity, ${ }^{4,9}$ anticonvulsant effect, ${ }^{10}$ analgesic and anti-inflammatory activities ${ }^{5}$ have been also reported.

Despite its reported therapeutic potentials, there is paucity of data on the haemostatic activities which gave the insight for the present study.

\section{Experimental}

\section{Procurement of experimental animals/Animal husbandry}

A total of 25 male wistar rats (four month old) weighing 75-120 g were purchased from the animal house, College of Medicine, University of Nigeria, Enugu campus. These animals were housed in a clean and properly ventilated wooden cage at room temperature, relative humidity of 20-40\% with consistent 12 hours of natural dark and light cycles and fed with specific feed and clean tap water ad libitum. The rats were allowed to acclimatize for 14 days. The protocol and animal use for the experiments 
were conducted according to the National Institute of Health Guide for Care and Use of Laboratory Animals (Pub No. 85-23, revised 1985) and with the University of Nigeria Ethics Committee on the use of laboratory animals, registered by the National Health Research Ethics Committee (NHREC/05/01/2020B).

\section{Collection and identification of plant material}

Fresh leaves of Persea americana was collected from a bush around the University of Nigeria, Enugu campus and identified and authenticated. The leaves were rinsed using distilled water and shade-dried. After drying the samples were reduced into fine powder by grinding.

\section{Sample preparation of extraction}

Leaf extraction was done according to the method of Jantan. ${ }^{11}$ Fresh leaves of Persea americana was washed in distilled water, shade-dried for one month and milled into a coarse powder using a house-made mill. About $100 \mathrm{~g}$ of the dried leaves were macerated in $1 \mathrm{~L}$ of absolute methanol at a ratio of 1:10 (w/v) and stirred for 1 hour at room temperature using an orbital shaker rotating at $250 \mathrm{rpm}$. The crude extract was filtered through Whatman filter paper No. 1 in order to obtain the residue. The residue was re-extracted twice to obtain pure samples, and the three extracts were combined. The resulted liquid was evaporated in a rotary evaporator at $40{ }^{\circ} \mathrm{C}$ under vacuum to lyophilize the crude extract and stored at $-20{ }^{\circ} \mathrm{C}$ for further analysis. Various concentrations $(200 \mathrm{mg} / \mathrm{kg}, 400 \mathrm{mg} / \mathrm{kg}, 600 \mathrm{mg} / \mathrm{kg}$ and $800 \mathrm{mg} / \mathrm{kg}$ body weight) of the plant extract were administered orally to the rats in groups B to E respectively, while the control group received normal feed and clean water. The administered extracts dosage was chosen according to Ikewuchi. ${ }^{12}$ 
Phytochemical screening of Persea americana leaves

Quantitative phytochemical screening of leaves was carried out according to $\mathrm{AOAC}^{13}$ method.

\section{Determination of $L D_{50}$}

To ascertain the lethal dose range as well as the safest range at which the plant extract should be administered, the acute toxicity $\left(\mathrm{LD}_{50}\right)$ of the extract was determined. The methanol extract was administered in normal saline solution. The test was carried out in two phases as according to Lorke ${ }^{14}$ using a batch of 13 mice each one having an weight of $25-32 \mathrm{~g}$. In the first phase, the animals were divided into 3 groups of 3 mice each, and the extract was administered at three different doses (10, 100 and $1000 \mathrm{mg} / \mathrm{kg}$ body weight). The treated animals were then monitored for one day. Based on preliminary results obtained from this first trial, the remaining animals were regrouped into 4 groups of one animal for second phase of the test. In this phase, 4 doses of $800,1600,2900$ and $5000 \mathrm{mg} / \mathrm{kg}$ body weight were used and the animals were closely examined for next 24 hours.

The groupings and dosage of administration of Persea americana leaf extract is shown in Table 1. Treatment lasted for thirty days in correspondence with the guiding principles for animal use in research. ${ }^{14}$

Table 1. Procedure for extract administration.

\begin{tabular}{ll}
\hline Group & \multicolumn{1}{c}{ Treatment } \\
\hline A (control) & Received normal feed and water daily for 30 days \\
B & $\begin{array}{l}\text { Normal feed, water and } 200 \mathrm{mg} / \mathrm{kg} \text { oral dose of Persea } \\
\text { americana leaf extract daily for } 30 \mathrm{days}\end{array}$ \\
$\mathrm{C}$ & $\begin{array}{l}\text { Normal feed, water and } 400 \mathrm{mg} / \mathrm{kg} \text { oral dose of Persea } \\
\text { americana leaf extract daily for } 30 \text { days }\end{array}$ \\
D & $\begin{array}{l}\text { Normal feed, water and } 600 \mathrm{mg} / \mathrm{kg} \text { oral dose of Persea } \\
\text { americana leaf extract daily for } 30 \text { days }\end{array}$ \\
E & $\begin{array}{l}\text { Normal feed, water and } 800 \mathrm{mg} / \mathrm{kg} \text { oral dose of Persea } \\
\text { americana leaf extract daily for } 30 \text { days }\end{array}$ \\
\hline
\end{tabular}


After oral administration of the leaf extract for 30 days, the five rats in each group were fasted overnight and anesthetized using chloroform. The rats were painlessly sacrificed by cardiac puncture and blood samples collected into EDTA sample bottle. The anti-coagulated blood in EDTA sample bottles was centrifuged at $1000 \mathrm{rpm}$ for 10 minutes to obtain plasma that was used for the analysis of prothrombin time, activated partial thromboplastin time, clotting time, bleeding time and plasma fibrinogen concentration. The process was repeated thrice for analysis on all samples.

\section{Haematological indices}

Prothrombin Time (PT)

The Quick's one stage method was adopted. Homogenized dehydrated plasma scan reagent $(0.1 \mathrm{~mL})$ (a freeze-dried calcium thromboplastin reagent commercially prepared) was added into a test tube containing $0.1 \mathrm{~mL}$ of plasma and was placed in water bath and allowed to stand for 2 minutes. A warmed $0.1 \mathrm{~mL}$ of $0.025 \mathrm{~mol} / \mathrm{L}$ calcium chloride was added into the mixture. The test tube was gently tilted back and forth in the water bath until a clot was formed and time was recorded. ${ }^{15}$

\section{Activated Partial Thromboplastin Time (APTT)}

In order to determine APTT values Proctor and Rapaport method ${ }^{16}$ was deployed. A well-mixed kaolin/ platelet substitute $(0.1 \mathrm{~mL})$ was added into a test tube containing $0.1 \mathrm{~mL}$ of plasma. The mixture was incubated at $37{ }^{\circ} \mathrm{C}$ for 2 minutes and $0.1 \mathrm{~mL}$ of pre-incubated calcium chloride was added and the clotting time was determined.

\section{Bleeding Time (BT)}

Bleeding time was estimated using Duke's method with slightly modification. A sharp puncture was made on the skin of the animal using a lancet and the bleeding time was recorded. The skin puncture was dabbed 
with a filter paper after every 15 seconds until no stain on the filter paper was seen. Thus the bleeding time was established. ${ }^{17}$

\section{Clotting Time (CT)}

Exactly $0.8 \mathrm{~mL}$ of blood was taken from each of the rats and splitted into $0.2 \mathrm{~mL}$ volumes five different pre-heated glass test tubes and maintained at $37^{\circ} \mathrm{C}$. The stopwatch was started as soon as the samples were transferred into the test tubes. The tubes were continually tilted every $30 \mathrm{~s}$ until the content stopped flowing when tilted at an angle of $90{ }^{\circ} \mathrm{C}$ and was carefully observed until the blood clotted in each of the test tubes. ${ }^{18}$

\section{Plasma fibrinogen concentration}

The Ingram ${ }^{19}$ method with slight modifications was deployed in determining the plasma fibrinogen concentration. Blood sample were transferred using plastic syringes into a glass vessel containing 3.2\% sodium citrate. The sample was centrifuged for 10 mins to obtain plasma. Exactly $0.2 \mathrm{~mL}$ of the blood plasma were pipetted into a test tube and incubated in a water bath for 4 minutes at $37{ }^{\circ} \mathrm{C}$. About $0.2 \mathrm{~mL}$ of thrombin time-reagent were transferred to test plasma, homogenized and the resulted clot harvested using a wooden applicator stick. The resulting clot was mixed with acetone an allowed to dry and harden for about 10 mins. Later the acetone was removed and the clot placed on a filter paper. After acetone evaporation the clot was then recovered and weighed.

Fibrinogen concentration of citrated plasma $(\mathrm{mg} / \mathrm{dl})=\frac{\text { clot weight }(\mathrm{mg})}{\text { plasma volume }(\mathrm{dl})}$ 
Statistical Analysis

Data were analyzed using statistical package for biological social sciences (SPSS), incident 21.0 software. The results were expressed as mean \pm standard deviation, the comparison for significance between the control and the experimental group was done by using analysis of variance and the level of significance was $\mathrm{P}<0.05$.

\section{Results}

Acute toxicity $\left(\mathrm{LD}_{50}\right)$ of the leaf extract of Persea Americana was above $5000 \mathrm{mg} / \mathrm{kg}$ as no death was recorded at the highest dose after 24 hours monitoring. There was no sign of weakness, anorexia or restlessness observed within 24 hours monitoring.

The results of the phytochemical content of Persea americana leaves is shown in Table 2, effect of the Persea americana extract on haemostatic parameters are expressed in Tables 3 and 4 while the body weight of rats displayed in Table 5.

Table 2. Phytochemical content of Persea americana leaves.

\begin{tabular}{ll}
\hline Parameters & Percentage (\%) \\
\hline Alkaloids & $0.48 \pm 0.04$ \\
Saponins & $1.42 \pm 0.05$ \\
Tannins & $0.93 \pm 0.03$ \\
Flavonoids & $7.66 \pm 0.35$ \\
Steroids & $2.01 \pm 0.26$ \\
Phenols & $3.20 \pm 0.12$ \\
\hline
\end{tabular}

Data are expressed as mean \pm standard deviation.

Table 2 revealed that the percentage of flavonoid $(7.66 \pm 0.35 \%)$ to be greater than alkaloids $(0.48 \pm 0.04 \%)$ content. 
Table 3. Effect of extract on the Prothrombin time and activated partial thromboplastin time.

\begin{tabular}{llllll}
\hline Parameters & $\begin{array}{c}\text { Group A } \\
\text { (control) }\end{array}$ & Group B Group C Group D Group E \\
\hline Prothrombin time (s) & $14.4 \pm 0.6$ & $13.5 \pm 0.2$ & $11.0 \pm 0.3^{*}$ & $11.5 \pm 0.6^{*}$ & $10.7 \pm 0.7^{*}$ \\
Activated partial & $43.5 \pm 1.8$ & $35.7 \pm 0.8^{*}$ & $29.5 \pm 1.5^{*}$ & $27.8 \pm 3.9^{*}$ & $23.3 \pm 1.1^{*}$ \\
thromboplastin time (s) & & & & \\
\hline $\begin{array}{l}\text { Data are expressed as mean } \pm \text { standard deviation. Values bearing * are considered } \\
\text { statistically significant at }(\mathrm{P}<0.05) \text { when compared with control. }\end{array}$
\end{tabular}

Table 3 displays that prothrombin time ranged from $10.7 \pm 0.7$ to $14.4 \pm 0.6 \mathrm{~s}$ while activated partial thromboplastin time ranged from $23.3 \pm 1.1$ to $43.5 \pm 1.8 \mathrm{~s}$.

Table 4. Effect of extract on clotting time, bleeding time and plasma fibrinogen concentration.

\begin{tabular}{llllll}
\hline Parameters & $\begin{array}{l}\text { Group A } \\
\text { (Control) }\end{array}$ & Group B & Group C & Group D & Group E \\
\hline Clotting time (s) & $324.7 \pm 5.2$ & $97.3 \pm 3.5^{*}$ & $81.5 \pm 1.8^{*}$ & $68.3 \pm 2.1^{*}$ & $51.3 \pm 1.2^{*}$ \\
Bleeding time (s) & $117.2 \pm 2.6$ & $84.6 \pm 12.4^{*}$ & $80.8 \pm 2.6^{*}$ & $72.5 \pm 1.6^{*}$ & $60.2 \pm 1.9^{*}$ \\
Plasma fibrinogen & $215.3 \pm 2.8$ & $232.3 \pm 5.9^{*}$ & $256.2 \pm 3.4^{*}$ & $268.7 \pm 4.1^{*}$ & $276.0 \pm 3.3^{*}$ \\
concentration \\
(mg/dL)
\end{tabular}

According with Table 4 the clotting time ranged from $51.3 \pm 1.2$ to $324.7 \pm 5.2 \mathrm{~s}$, bleeding time ranged from $60.2 \pm 1.9$ to $117.2 \pm 2.6 \mathrm{~s}$ while plasma fibrinogen concentration ranged from $215.3 \pm 2.8$ to $276.0 \pm 3.3 \mathrm{~s}$.

Table 5. Effects of extracts on the body weight of the rats.

\begin{tabular}{llllll}
\hline Treatment & Day 1 & Day 7 & Day 14 & Day 21 & Day 28 \\
\hline Control & $110.30 \pm 3.75$ & $112.13 \pm 3.35$ & $109.25 \pm 4.82$ & $110.75 \pm 4.43$ & $113.56 \pm 7.55$ \\
$200 \mathrm{mg} / \mathrm{kg}$ & $108.85 \pm 3.65$ & $113.17 \pm 3.47$ & $120.95 \pm 4.06$ & $124.75 \pm 4.67$ & $126.08 \pm 3.34$ \\
$400 \mathrm{mg} / \mathrm{kg}$ & $109.38 \pm 2.82$ & $115.64 \pm 3.64$ & $119.50 \pm 2.82$ & $123.70 \pm 5.32$ & $128.25 \pm 5.31$ \\
$600 \mathrm{mg} / \mathrm{kg}$ & $112.52 \pm 4.04$ & $117.40 \pm 2.23$ & $121.57 \pm 4.09$ & $125.4 .87 \pm 4.17$ & $130.41 \pm 4.22$ \\
$800 \mathrm{mg} / \mathrm{kg}$ & $118.43 \pm 5.67$ & $123.10 \pm 5.20$ & $125.32 \pm 6.42$ & $129.42 \pm 6.28$ & $133.32 \pm 5.45$ \\
\hline
\end{tabular}

Data are expressed as mean \pm standard deviation. 
Table 5 revealed a steady increase in the body weight of rats as the extract dose increased.

\section{Discussion}

The phytochemical screening of Persea americana leaf revealed the presence of alkaloids, tannins, flavonoids, saponins, steroids and phenols (Table 2). Arukwe et al. ${ }^{20}$ had earlier revealed the qualitative determination of phytochemical constituents of the leaf, fruit and seed of Persea americana. Tannins are inhibitors of digestive enzymes and form protein complexes, ${ }^{20}$ while flavonoids are acting as antioxidants and free radical scavengers that slow down oxidative cell damage and inhibit the activities of carcinogens. ${ }^{20}$ Tannin value recorded in this study was lower when compared to the studies on analysis and phytochemical screening of fluted pumpkin (Telfairia occidentalis) pod. ${ }^{20,21}$ Moreover, the percentage of flavonoids obtained in this study was lower than the findings of Arukwe et al., ${ }^{20}$ but higher than the ones of Akwukwaegbu et al. ${ }^{21}$

The results from the laboratory analysis of the PT and APTT were illustrated in Table 3 . The results revealed that there was a significant decrease $(\mathrm{P}<0.05)$ in the $\mathrm{PT}$ in groups $\mathrm{C}, \mathrm{D}$ and $\mathrm{E}$, when compared with the control, but was insignificant in group B. Similarly, there was a significant decrease in the activated partial thromboplastin time $(\mathrm{P}<0.05)$ for all test groups when compared with the control. The decrease could be said to have occurred in a dose dependent manner with the rats in group E recording the lowest value for both parameters.

The process involved in the transformation of blood from a liquid state to a solid state requires a chain of enzyme activation and inhibition. ${ }^{22}$ Over the course of time, blood coagulation turned out to be a highly sophisticated defense mechanism able to detect body's injuries and prevent 
death by excessive blood loss. ${ }^{23-27}$ The ethnomedicinal use of plant extracts in preventing excessive blood flow in the event of an injury is a common worldwide old practice. In this study, the effects of methanolic extracts of Persea americana was investigated to ascertain the extent to which they can affect some of the haemostatic parameters (prothrombin time, activated partial thromboplastin time, clotting time, bleeding time, and plasma fibrinogen concentration) analyzed in the work. The study paid specific attention to how much these indices prolonged or shortened these haemostatic indices frequently used in ascertaining coagulation rates. They are used in clinical chemistry to evaluate the ability of blood to form clots appropriately within a specific period of interval and also to assess the amount and function of proteins referred to as coagulation factors as key elements of blood clot formation. The PT test evaluates how well all of the coagulation factors, such as factors I (fibrinogen), II (prothrombin), V, VII and $\mathrm{X}$ are working together. PT/INR and APTT estimation is useful in order to evaluate the clotting factors. These proteins (XII, XI, IX, VII, X, V, II-Prothrombin and I-fibrinogenas well as prekallikrein -PK and high molecular kininogen-HK) are part of the extrinsic and common pathways. One deficiency is associated with prolonged parameters. From the result, it was seen that the values of PT decreased as the dosage of the extracts increased and was statistically significant following the administration of $400 \mathrm{mg} / \mathrm{kg}, 600 \mathrm{mg} / \mathrm{kg}$ and $800 \mathrm{mg} / \mathrm{kg}$ of the extracts, when compared with the control group $(\mathrm{P}<0.05)$. The APTT values on the other hand were seen to decrease as well, and showed a statistical significance difference at the administration of dosage $200 \mathrm{mg} / \mathrm{kg}, 400 \mathrm{mg} / \mathrm{kg}, 600 \mathrm{~kg} / \mathrm{mg}, 800 \mathrm{mg} / \mathrm{kg}$ of the plant extract. According to other studies, the decrease in the values of PT and APTT could be attributed to actions of some phytochemical 
parameters resident in the plants such as tannins and flavonoids which have been known to promote coagulation. ${ }^{28}$ Tannins might regulate haemostatic activity of plants being involved in bleeding arrest by precipitating proteins and forming vascular plugs. ${ }^{28}$ The findings on the PT and APTT obtained in this study agree with the report of: Essien et al. ${ }^{29}$ who observed a decrease in PT and APTT by Fagara xanthoxyloides extract, Bamidele et al. ${ }^{18}$ on haemostatic effect of methanolic leaf extract of Ageratum conyzoidesin albino rats and Nor et al. $^{30}$ who observed the in vitro antiatherothrombotic effects of extracts from Berberis vulgaris L., Teucriumpolium L., and Orthosiphonstamineus benth. However, the result correlates with a study conducted on blood coagulation activities of the leaf extracts of Ocimum gratissimum reported by Edemeka et al. ${ }^{31}$

The effect of extract on clotting time, bleeding time and plasma fibrinogen concentration are shown in Table 4. From the result, it was seen that the plant extract significantly reduced $(\mathrm{P}<0.05)$ the clotting time and bleeding time in all the test groups when compared with the control. On the contrary, the extract significantly increased $(\mathrm{P}<0.05)$ the plasma fibrinogen concentration in the test groups when compared with the control.

Clotting time is the time required for a sample of blood to coagulate under standard conditions while bleeding time is used to ascertain how quickly the blood clots in other to stop bleeding. Bleeding time is used in the laboratory to assess platelet function. It seeks to measure the factors involved in the intrinsic pathway of the coagulation cascade. ${ }^{17,32}$ If one of the coagulation factors in the intrinsic pathways such as factor I, II, V, VIII, IX, X, XI or XII is deficient, the test values of clotting time will be affected. The result on the clotting time and bleeding time obtained in this study was in line with the work of Okoli et al., ${ }^{28}$ on the haemostatic activities of 
Aspilia africana extracts. People with hemophilia lack certain clotting factors which are essential for blood clotting.

Fibrinogen is synthesized in the hepatocytes and it plays an essential role in platelet aggregation. It is one of the crucial plasma protein coagulation factors. If the concentrations of plasma fibrinogen are typically low, there would be an associated risk of bleeding as a result of impaired haemostasis.

The body weights of the rats were taken at the end of the $7^{\text {th }}$ day throughout the period of the study and from the result, it can be seen that the body weights increased relatively from the $7^{\text {th }}$ day through to the $28^{\text {th }}$ day (Table 5). The control group had no significant increase in their body weights. The increase in body weights could be attributed to the administration of the extract which possibly stimulated appetite in the rats and enhanced their food intake.

\section{Conclusions}

In conclusion, methanolic extract of Persea americana leaves decreased prothrombin time, activated partial thromboplastin time, bleeding time, clotting time and increased plasma fibrinogen concentration. This appropriately lends support in its use in traditional medicine practice for wound healing and in the management of bleeding disorders. There is room for further research on the fractionation and isolation of the bioactive compounds in plant extract responsible for the coagulation properties.

\section{Acknowledgement}

The authors are grateful to life chart diagnostic center where this research work was carried out. 


\section{References}

1. Furie, B.; Furie, B. C. Molecular and cellular biology of blood coagulation, N. Engl. J. Med. 1992, 326-800.

2. Pallister, C. J.; Watso, M. S. Hematology, Second edition, Scion publishing Ltd, 1999.

3. Yasir, M.; Das, S.; Kharya, M.D. The phytochemical and pharmacological profile of Persea americana mill. Phcog. Rev. 2010, 4(7), 77-84.

4. Ojewole, J. A. O.; Kamadiyaapa, D.; Gondwe, M. M.; Moodley, K.; Musabayane, C. T. Cardiovascular effects of Persea americana mill (Lauraceae) (avocado) aqueous leaf extract in experimental animals. Cardiovasc. J. S. Afr. 2007, 18(2), 69-76.

5. Adeyemi, O. O.; Okpo, S. O.; Ogunti, O. O. Analgesic and antiinflammatory effects of the aqueous extract of leaves of Persea americana mill (Lauraceae). Fitoterapia 2000, 73, 375-380.

6. Lans, A. L. Ethnomedical used on Trinidad and Tobago for urinary problems \& diabetes mellitus. J. Ethnobiol. Ethnomed. 2006, 2(45), 1-11.

7. Bartholomew, I. C. B.; Odetola A. A.; Agomo, P. U. Hypoglycaemic and hypocholesterol potential of Persea americana leaf extract. J. Med. Food 2007, 10(2), 356-360.

8. Gill, L. S. Ethnomedical uses of plants in Nigeria, Uniben press Benin Nigeria, 1992.

9. Owolabi, M. A.; Jaja, S. I.; Coker, H. A. B. Vaso relaxant action of aqueous extract of the leaves of the Persea americana on isolated thoracic rat aorta. Fitoterapia 2005, 76(6), 567-573.

10. Ojewole, J. A.; Amabeoku, G. Anticonvulsant effect of Persea Americana mill (Lauraceae) (Avocado) leaf aqueous extract in mill, Phytother. Res., 2006, 20(8), 696-700.

11. Saputri F. C.; Jantan, I. Effects of selected medicinal plants on human low-density lipoprotein oxidation, 2, 2-diphenyl-1-picrylhydrazyl (DPPH) radicals and human platelet aggregation, J. Med. Plants Res. 2011, 5(26), 6182-6191.

12. Ikewuchi, C. C.; Ayalogu, E. O.; Onyeike E. N.; Ikewuchi, J. C. Effect of aqueous extract of the leaves of Sansevieria liberica Gérôme and 
Labroy on blood pressure indices and pulse rates of sub-chronic saltloaded rats, J. Nat. Rem. 2011, 11(2), 30-38.

13. Association of Official Analytical Chemists, Method of analysis, Washington DC, U.S., 1990, pp. 1250-1255.

14. Lorke D., A new approach to practical acute toxicity testing. Arch. Toxicol. 1983, 54, 275-287.

15. Brown, B. A., Haematology: Principles and procedures, Lea and Febiger, Philadelphia, Pa, USA, 5th edition, 1988.

16. Proctor, R. R.; Rapaport, S. I. The partial thromboplastin time with kaolin, A simple screening time test for the first stage plasma clotting factor deficiencies. Am. J. Clin. Pathol. 1961, 36, 212-219.

17. Ochei, J.; Kolhatkar, A. Medical laboratory science, Theory and practice. Tata Mcgraw-Hill Publishing Company Limited, New Delhi, $2^{\text {nd }}$ edition, pp. 332-349.

18. Bamidele, O.; Akinnuga, A. M.; Anyakudo, M. M. C.; Ojo O. A.; Ojo, G. B.; Olorunfemi, J. O.; Johnson, O. P. Haemostatic effect of methanolic leaf extract of Ageratum conyzoidesin albino rats, J. Med. Plants Res. 2010, 4(20), 2075-2079.

19. Ingram, G. I. A suggested schedule for the rapid determination of acute haemostatic failure, J. Clin. Pathol. 1961, 14(4), 356-360.

20. Arukwe U.; Amadi, B. A.; Duru, M. K. C.; Agomo, E. N.; Adindu, E. A.; Odika, P. C.; Lele, K. C.; Egejuru L.; Anudike, J. Chemical composition of Persea americana leaf, fruit and seed. Int. J. recent res. Appl. Stud. 2012, 11(2), 346-349.

21. Akwukwaegbu, P. I.; Peters, D. E.; Wegwu, M. O. Proximate analysis and phytochemical screening of fluted pumpkin (Telfairiaoccidentalis) pod. Am. J. Food Nutr. Health 2016, 1(1), 1-6.

22. Kenichi, A. T.; Nigel, S. K.; Jerrold, H. L. Blood coagulation: Hemostasis and thrombin regulation. Anesth. Analg. 2009, 108(5), 1433-1446.

23. Patthy, L. Evolution of the proteases of blood coagulation and fibrinolysis by assembly from modules. Cell 1985, 41, 657-663.

24. Lindqvist, P. G.; Svensson, P. J.; Dahlback, B.; Marsal, K. Factor VQ506 mutation (activated protein $\mathrm{C}$ resistance) associated with 
reduced intrapartum blood loss - a possible evolutionary selection mechanism. Thromb. H aemost. 1998, 79(1), 69-73.

25. Krem, M. M.; Di Cera, E. Molecular markers of serine protease evolution, Eur. Mol. Bio. Org. J. 2001, 20(12), 3036-3045.

26. Davidson, C. J.; Tuddenham, E. G.; McVey, J. H. 450 million years of hemostasis, J. Thromb. Haemost. 2003, 1(7), 1487-1494.

27. Theopold, U.; Schmidt, O.; Soderhall, K.; Dushay, M. S. Coagulation in arthropods: defence, wound closure and healing, Trends Immunol. 2004, 25(6), 289-294.

28. Okoli, C. O.; Akah P. A.; Okoli, A. S. Potentials of leaves of Aspilia Africana (compositae) in wound care; an experimental evaluation. BMC Complement. Altern. Med. 2007, 7(10), 1186-1472.

29. Essien, E. M.; Okogun J. I.; Adelakun, A. Blood coagulation activities of the root extract of Fagara xanthoxylodes, Afric. J. Med. 1985, 14(2), 83-88.

30. Nor, N. H. M.; Othman, F.; Tohit, E. R. M.; Noor, S. B.; Razali, R.; Hassali, H. A.; Hassan, H. In vitro antiatherothrombotic effects of extracts from Berberis vulgaris L., Teucriumpolium L., Orthosiphonstamineus benth. Evi. Based Compl. Altern. Med. 2019, 3(1), 1-10.

31. Edemeka, D. B. U.; Ogwu, A. S. Blood coagulation activities of the leaf extracts of Ocimum gratissimum plant in Man. J. Herbs Spices Med. Plants 2009, 7(4), 9-14.

32. Dapper, D. V.; Achinike, P. N.; Gwotmut, M. D. Effects of Aloe vera (gel) on clotting time, prothrombin time and plasma fibrinogen concentration in albino wistar rats, Port Harcourt. Med. J. 2007, 2(1), 56-60. 